\title{
Use of Vegetative Wastewater Treatment Systems for Counties' Effluent Management in Kenya
}

\author{
Lynette K. Bundi ${ }^{1, a^{*}}$ and Catherine W. Njeru ${ }^{2, b}$, \\ ${ }^{1}$ Engineering Student, Department of Environmental and Bio-Systems Engineering, University of Nairobi, \\ P. O. Box 30197-00100, Nairobi, Kenya. \\ ${ }^{2}$ Research Assistant, GLOBTEK CONSULT Limited, P.O Box 70774-00400, Nairobi, Kenya. \\ a lynettekinya@gmail.com, ${ }^{\mathrm{b}}$ njerukt22@gmail.com
}

\begin{abstract}
In Kenya, the devolved system of governance to counties is currently facing many challenges in the provision of basic services including wastewater management. Thus there is an attempt to explore the feasibility of using vegetative wastewater treatment systems that are economically viable and environmentally sustainable. The viable options available include: Constructed wetlands; use of micro-algae and the use of Moringa Oleifera, as an herbal coagulant.

Constructed wetlands treatment systems are engineered systems that consist of two general categories namely: subsurface flow systems and free water surface systems. The subsurface flow systems have also been referred to as root zone systems; rock reed filters and vegetated submerged bed systems. Free water surface systems are frequently designed to maximize wetlands habitat values and reuse opportunities, while providing effective water quality improvement.

Microalgae culture offers an interesting step for wastewater treatments, because they provide a tertiary biotreatment coupled with the production of potentially valuable biomass, which can be used for several purposes. Microalgae cultures offer an elegant solution to tertiary and quandary treatments due to the ability of microalgae to use inorganic nitrogen and phosphorus for their growth. And also, for their capacity to remove heavy metals, as well as some toxic organic compounds, therefore, it does not lead to secondary pollution.

The use of Moringa Oleifera, an herbal coagulant, which is free of constraints viz. $\mathrm{pH}$ and alkalinity, has been used to reduce wastewater pollution significantly in some studies. The results of the studies showed that an optimum dose of Moringa Oleifera $(60 \mathrm{mg} / \mathrm{L})$ was observed to reduce pollution parameters - initial $\mathrm{BOD}_{5}$ and COD of dairy wastewater to the tune of $55 \%$ and $60 \%$ respectively.

This review highlights on the use of vegetative wastewater treatment systems like constructed wetlands, micro-algae and Moringa Oleifera in effluent management in counties of Kenya.
\end{abstract}

Keywords: constructed wetlands, micro-algae, Moringa Oleifera, wastewater, faecal coliforms, coagulation.

\section{Introduction to Wastewater}

Expansion of urban populations and increased coverage of domestic water supply and sewerage give rise to greater quantities of municipal wastewater. With the current emphasis on environmental health and water pollution issues, there is an increasing awareness of the need to dispose of these wastewaters safely and beneficially. Use of wastewater in agriculture could be an important consideration when its disposal is being planned in arid and semi-arid regions. However it should be realized that the quantity of wastewater available in most countries will account for only a small fraction of the total irrigation water requirements. Nevertheless, wastewater use will result in the conservation of higher quality water and its use for purposes other than irrigation. As the marginal cost of alternative supplies of good quality water will usually be higher in water-short areas, it makes good sense to incorporate agricultural reuse into water resources and land use planning. 
Properly planned use of municipal wastewater alleviates surface water pollution problems and not only conserves valuable water resources but also takes advantage of the nutrients contained in sewage to grow crops. The availability of this additional water near population centres will increase the choice of crops which farmers can grow. The nitrogen and phosphorus content of sewage might reduce or eliminate the requirements for commercial fertilizers. It is advantageous to consider effluent reuse at the same time as wastewater collection; treatment and disposal are planned so that sewerage system design can be optimized in terms of effluent transport and treatment methods. The cost of transmission of effluent from inappropriately sited sewage treatment plants to distant agricultural land is usually prohibitive. Additionally, sewage treatment techniques for effluent discharge to surface waters may not always be appropriate for agricultural use of the effluent.

Municipal wastewater is mainly comprised of water $(99.9 \%)$ together with relatively small concentrations of suspended and dissolved organic and inorganic solids. Among the organic substances present in sewage are carbohydrates, lignin, fats, soaps, synthetic detergents, proteins and their decomposition products, as well as various natural and synthetic organic chemicals from the process industries.

Municipal wastewater also contains a variety of inorganic substances from domestic and industrial sources, including a number of potentially toxic elements such as arsenic, cadmium, chromium, copper, lead, mercury, zinc, etc. Even if toxic materials are not present in concentrations likely to affect humans, they might well be at phytotoxic levels, which would limit their agricultural use. However, from the point of view of health, a very important consideration in agricultural use of wastewater, the contaminants of greatest concern are the pathogenic micro- and macro-organisms.

Table 1: Pathogenic organisms commonly found in wastewater [Biamah, 2004]

\begin{tabular}{|c|c|c|}
\hline Organisms & Diseases & Remarks \\
\hline $\begin{array}{l}\text { Askaris spp } \\
\text { Enterobius spp }\end{array}$ & Nematode worms & $\begin{array}{l}\text { Dangerous to man .Found in wastewater } \\
\text { effluent and dried sludge used as fertilizers. }\end{array}$ \\
\hline Bacillus anthracis & Anthrax & $\begin{array}{l}\text { Found in wastewater, spores are resistant to } \\
\text { treatment. }\end{array}$ \\
\hline Brucella spp & $\begin{array}{l}\text { Brucellosis, night } \\
\text { fever in man; } \\
\text { contagious abortion } \\
\text { in sheep, goats and } \\
\text { cattle. }\end{array}$ & $\begin{array}{l}\text { Normally transmitted by infected milk or } \\
\text { by contact. Wastewater is also suspected. }\end{array}$ \\
\hline $\begin{array}{l}\text { Entamoeba } \\
\text { Histolytica }\end{array}$ & Dysentery & $\begin{array}{l}\text { Spread by contaminated water and sludge } \\
\text { used as fertilizer.Common in hot climates }\end{array}$ \\
\hline $\begin{array}{l}\text { Leptospira } \\
\text { iceterohaemorrha } \\
\text { geiae }\end{array}$ & $\begin{array}{l}\text { Leptospirosis (wells } \\
\text { sewage disease). }\end{array}$ & Carried by sewer rats. \\
\hline $\begin{array}{l}\text { Mycobacterium } \\
\text { tuberculosis }\end{array}$ & Tuberculosis & $\begin{array}{l}\text { Isolated from wastewater and polluted } \\
\text { streams. Wastewater is a possible mode of } \\
\text { transmission. Care must be taken with } \\
\text { wastewater and sludge from Santeria. }\end{array}$ \\
\hline Salmonella & Paratyphoid fever & Common in wastewater effluents in times \\
\hline
\end{tabular}




\begin{tabular}{|l|l|l|}
\hline paratyphi & of epidemics. \\
\hline Salmonella typhi & Typhoid fever & $\begin{array}{l}\text { Common in wastewater effluents in times } \\
\text { of epidemics. }\end{array}$ \\
\hline Salmonella spp & Food poisoning & Common in wastewater effluents. \\
\hline Schistosoma spp & schistosomiasis & Killed by efficient wastewater treatment \\
\hline Shigella spp & Bacillary dysentery & $\begin{array}{l}\text { Polluted water bare main source of } \\
\text { infection }\end{array}$ \\
\hline Taenia spp & tapeworms & $\begin{array}{l}\text { Eggs very resistant, present in wastewater } \\
\text { sludge and effluent danger to cattle.on } \\
\text { sewage irrigated land or land manured with } \\
\text { sludge }\end{array}$ \\
\hline Vibrio cholerae & Cholera & $\begin{array}{l}\text { Transmitted by wastewater and polluted } \\
\text { waters. }\end{array}$ \\
\hline
\end{tabular}

Selection of a wastewater treatment process or sequence of processes depends on a number of various factors namely:-

a) Characteristics of wastewater such as the BOD5, percent of suspended solids, $\mathrm{pH}$ and presence of toxic materials

b) Required effluent quality if the river or water body into which the treated wastewater is discharged is used by a community downstream

c) Cost and availability of land; certain biological processes like constructed wetlands are economically feasible only if low cost land is available.

d) Consideration of a possible future upgrading of water quality standards necessitating design of a more sophisticated type of treatment for future use.

\section{Vegetative Wastewater Treatment; Available Technologies}

Vegetative Wastewater treatment is a process used to convert wastewater - which is water no longer needed or suitable for its most recent use - into an effluent that can be either returned to the water cycle with minimal environmental issues or reused using environmental friendly methods and applying no chemicals. The latter is called water reclamation and implies avoidance of disposal by use of treated wastewater effluent for various purposes. Treatment means removing impurities from water being treated; and some methods of treatment are applicable to both water and wastewater.

The available technologies such as: constructed wetlands, micro-algae and Moringa Oleifera are discussed below.

a.Constructed wetlands for wastewater treatment: Constructed wetlands are complex, integrating systems in which water, plants, animals, micro-organisms, the environment, sun, soil, and air interact to improve water quality. Whereas geology, hydrology and biology create natural wetlands, constructed wetlands are the result of human skills and technology; they are engineered systems designed to utilize natural processes, vegetation soil and microbial assemblages [Butijin \& Greiner, 1985].

Constructed wetlands are increasingly being used in Kenya to treat wastewater. The first installation that came on line in 1994 now handless up to 800,000 liters of wastewater daily (a residential person 
equivalent of 1200) from the busy Carnivore Restaurant and Splash Water-world Park in Nairobi. There are now about 10 fully operational constructed wetlands in Kenya, with KAPA Oil Refineries enjoying the latest experience and benefits of the technology.

Although a primary purpose of constructed wetlands is to treat various kinds of wastewater, the facilities usually serve other purposes as well. A wetland can serve as a wildlife site, to attract various animals and provide habitat. Again, a wetland can be a public attraction point welcoming visitors to explore its environment and educational possibilities.

Constructed wetland systems are subject to close control and are designed to maximize treatment efficiency and biomass production, with the shape of artificial wetlands made to facilitate harvesting. They can be used in all climates and provide a valuable habitat for wildlife, [Carnivore, 2006].

In terms of cost, they require a large area of land, a high degree of labour to construct the bed and plant the vegetation; and periodic harvesting. However, they are more cost-effective on a long term basis than natural wetlands.

Artificial wetlands function in the same way as natural ones except that more nitrogen and phosphorus is lost from the system by harvesting. Three plants are usually used to treat the wastewater; Scirpus validus (bulrush), Phragmites communis (common reed) and Typha latifolia (cattail).

If properly built, maintained and operated, artificial wetlands can effectively remove many pollutants associated with municipal \& industrial wastewater and storm water. Such systems are especially efficient at removing contaminants such as $\mathrm{BOD}_{5}, \mathrm{COD}$, suspended solids, nitrogen, phosphorous, hydrocarbons and even metals.

They have successfully been used to treat municipal effluent, industrial \& commercial wastewater, agricultural runoff, storm water, animal wastes, acid mine drainage and landfill leachates [Butijin \& Greiner, 1985].

Wastewater treatment by constructed wetlands is an environmentally sound process. Besides the reduction in the levels of effluent oxygen demand and bacteriological load, constructed wetlands (CWs) have also displayed considerable capacity in the removal of nitrates, phosphates and ammonia which are responsible for eutrophication, as well as hazardous heavy metal pollutants. Conventional wastewater treatment relies on machinery and chemicals-lag detention in attractive and expensive concrete ponds, then stirring and aeration using machinery powered by electricity or fossil fuels, followed by chemical treatment to ensure compliance with public health criteria be even if the sewage is not to be reused. These systems have high operational costs, frequent mechanical breakdowns and unavailability of spare parts and are susceptible to power cuts. Such high-tech and in appropriate solutions to wastewater management and treatment tend to be non-sustainable.

Although a primary purpose of constructed wetlands is to treat various kinds of wastewater, the facilities usually serve other purposes as well. Research will be conducted to study and evaluate the workings of the wetland process. A wetland also can serve as a wildlife site, to attract various animals and provide habitat. Again, a wetland can be a public attraction point welcoming visitors to explore its environment and educational possibilities.

All these systems comply with responsible discharge criteria and between them return million liters of water daily to the various surface water systems. In some cases, the discharge is actually cleaner than the receiving waters. 
b.Micro-algae and Wastewater Treatment: Organic and inorganic substances which are released into the environment as a result of domestic, agricultural and industrial water activities lead to organic and inorganic pollution, [Gray, N.F. (1989].

The normal primary and secondary treatment processes of these wastewaters have been introduced in a growing number of places in order to eliminate the easily settled materials and to oxidize the organic material present in wastewater.

The final result is a clear, apparently clean effluent which is discharged into natural water bodies. This secondary effluent is, however, loaded with inorganic nitrogen and phosphorus and causes eutrophication and more long-term problems because of refractory organics and heavy metals that are discharged.

Microalgae culture offers an interesting step for wastewater treatments, because they provide a tertiary bio-treatment coupled with the production of potentially valuable biomass, which can be used for several purposes.

Microalgae cultures offer an elegant solution to tertiary and quandary treatments due to the ability of microalgae to use inorganic nitrogen and phosphorus for their growth. And also, for their capacity to remove heavy metals, as well as some toxic organic compounds, therefore, it does not lead to secondary pollution.

Wastewater environment is an ideal media for a wide range of microorganisms specially bacteria, viruses and protozoa. The majority is harmless and can be used in biological sewage treatment, but sewage also contains pathogenic microorganisms, which are excreted in large numbers by sick individuals and a symptomic carrier.

\section{c.Moringa Oleifera seed as a natural coagulant for water and wastewater treatment: Moringa} Oleifera is a multipurpose tree of considerable potential and its cultivation is currently being actively promoted in many developing countries. The various uses and products of the tree are given.

Seeds of this pan tropical tree contain water soluble, positively charged proteins that act as an effective coagulant for water and wastewater treatment

Coagulation-flocculation followed by sedimentation, using chemical coagulant is a very common treatment method used mainly in water treatment practices.

Recently there has been more interest, especially in developing countries, in possible application of herbal coagulants.

Use of Moringa oleifera (Drumsticks seed) as herbal coagulant is reported to be quite effective and have many advantages over chemical coagulant like Alum.

Recent studies have pointed out several serious drawbacks of using aluminium salts, such as Alzheimer's disease and similar health related problems associated with residual aluminium in treated waters, [Forklard, et. al, 1990].

Moringa Oleifera herbal coagulant is reported to be efficient in removal of turbidity from waters. Possibility of its use in the primary treatment of industrial wastewater was explored.

The M.Oleifera tree is a native of Northern India, which now grows widely throughout the tropics. English vernacular names include drumstick (shape of the pods) and horseradish (taste of the roots). It may be propagated from seeds or cuttings, grows well even in poor soils requiring minimal horticultural attention and is able to survive long periods of drought.

Extended and multiple harvests in a single year are evident in many parts of the world, [Sutherland et. al, 1990]. 
River water drawn for human consumption and general household use can be highly turbid particularly in the rainy season. River silt is churned into suspension and run off from fields and other surfaces carries solid material, bacteria and other microorganisms into the river. It is of paramount importance to remove as much of this suspended matter as possible prior to a disinfection stage and subsequent consumption. This can generally only be achieved by the addition of coagulants to the raw water, within a controlled treatment sequence. In many developing countries, proprietary chemical coagulants, such as aluminium sulphate and synthetic polyelectrolytes are either not available locally or are imported using foreign exchange.

Moringa derived coagulants offers several advantages over conventional coagulants such as aluminium sulphate:

- Activity is maintained over a wide range of influent $\mathrm{pH}$ values - no $\mathrm{pH}$ correction required

- Natural alkalinity of the raw water is unchanged following coagulation - no addition of alkalinity required

- Sludge production is greatly reduced and is essentially organic in nature with no aluminium residuals - sludge volumes are reduced by a factor of up to 5, [Ndabigengesere. et al, 1998]

However, there are many unresolved issues relating to the commercial viability of the scale-up of protein separation including;

- Technical feasibility/applicability of the scale-up of laboratory unit processes that comprises the sequence of separation

- Cost of production and the overall economics from cultivation, seed purchase, harvesting, oil extraction and sales, development of various commercial markets etc.

- Final desired form of the protein products - concentrated solutions / dried products

- Stability of protein products in storage

- Ease of preparation of dosing solutions for treatment applications

- Quality control and acceptable levels of impurities

- Regulatory aspects

\section{Conclusions}

The above discussed available technologies for wastewater treatment are viable and currently being adopted largely within Kenya and other developing countries. There is no chemical used in the vegetative wastewater management hence the methods are environment friendly. The main challenge as to why the vegetative methods of wastewater management have not completely picked up is lack of awareness on the ground.

A growing number of studies have provided evidence that many wetland systems are effective means of improving water quality without creating problems for wildlife survival. Algae can be used in wastewater treatment for a range of purposes, including; reduction of BOD, removal of $\mathrm{N}$ and/or $\mathrm{P}$, inhibition of coliforms, and removal of heavy metals.

The high concentration of $\mathrm{N}$ and $\mathrm{P}$ in most wastewaters also means these wastewaters may possibly be used as cheap nutrient sources for algal biomass production. This algal biomass could be used for; methane production, composting, production of liquid fuels ((pseudo-vegetable fuels), as animal feed or in aquaculture and production of fine chemicals. 
Promotion and development of Moringa Oleifera as a natural coagulant offers many diverse advantages to many countries of the developing world; sustainable, appropriate, effective and robust water treatment, effective enhancement of particular wastewater treatment processes, decreased reliance on the importation and distribution of treatment chemicals, the creation of a new cash crop for farmers and employment opportunities .Many technical and economic issues remain to be resolved with regard to the extraction and purification of the active components within the seed kernel. Vegetative wastewater water treatment is the way to go and therefore more research, sensitization and funding on the same should be done.

\section{References}

[1] Biamah, E. K. and Otieno, K.O (2004). Constructed Wetlands for Kaputiei Town Site, Kisaju, Kajiado, Kenya.

[2] Bujitin, G. D. and Greiner R. W., 1985. Artificial Wetlands as Tertiary Treatment Systems. Water, Science and Technology, Vol. 17 No. 4

[3] Carnivore (2006): Carnivore Constructed Wetland Manual. Carnivore Restaurant, Nairobi, Kenya

[4] Gray, N.F. (1989). Biology of Wastewater Treatment. Oxford University Press, New York.

[5] Folkard, G.K., Sutherland, J.P. \& Shaw, R. 1999, Water clarification using Moringa oleifera seed coagulant. In; Shaw, R. (ed), Running Water. Pub: Intermediate Technology Publications, London, ISBN 1-85339-450-5, pp 109-112.

[6] Ndabigengesere, A. \& Narasiah, K.S. 1998, Quality of water treated by coagulation using Moringa oleifera seed, Water Research, $\underline{32}$, 3, pp 781-791.

[7] Sutherland, J.P., Folkard, G.K. \& Grant, W.D. 1990, Natural coagulants for appropriate water treatment - a novel approach, Waterlines, April, $\underline{8}$, (4), pp 30-32.

[8] Kalogo, Y. \& Verstraete, W. 2000, Technical feasibility of the treatment of domestic wastewater by a CEPS-UASB system, Environmental Technology, 21, pp 55-65 